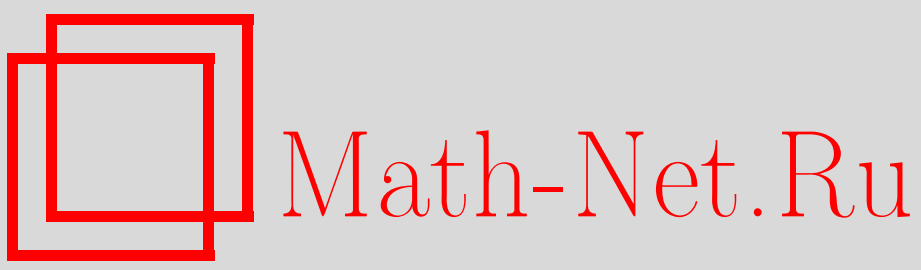

Дмитрий Викторович Аносов (к шестидесятилетию со дня рождения), Матем. заметки, 1996, том 60 , выпуск 6,803

DOI: https://doi.org/10.4213/mzm1897

Использование Общероссийского математического портала MathNet.Ru подразумевает, что вы прочитали и согласны с пользовательским соглашением

http://www.mathnet.ru/rus/agreement

Параметры загрузки:

IP : 54.89 .56 .158

26 апреля 2023 г., 14:36:28

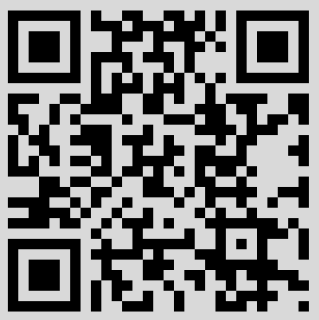




\section{Дмитрий Викторович Аносов \\ (к шестидесятилетию со дня рождения)}

30 ноября 1996 г. исполнилось 60 лет выдающемуся математику, заместителю главного редактора журнала «Математические заметки», заведующему лабораторией динамических систем Математического института им. В.А. Стеклова РАН, лауреату Ленинской премии, академику Д.В. Аносову.

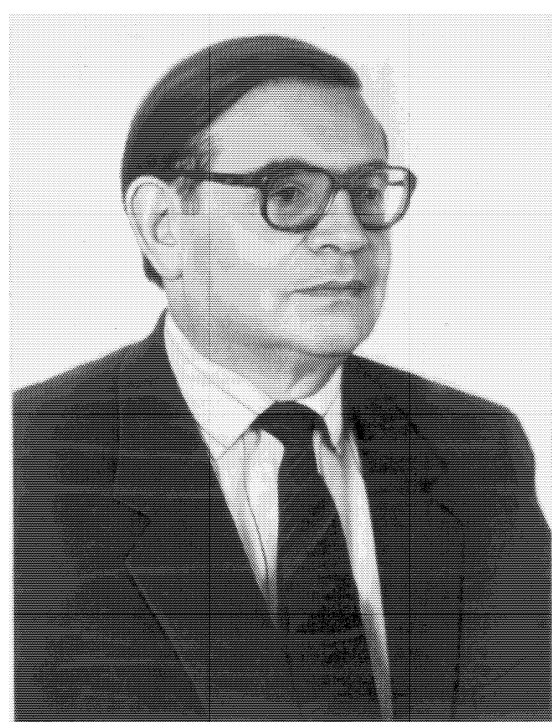

Фундаментальные результаты Д.В. Аносова оказали определяющее влияние на развитие теории динамических систем, ряда направлений эргодической теории и теории обыкновенных дифференциальных уравнений. Плодотворна его педагогическая и научно-организационная деятельность.

Горячо поздравляем Дмитрия Викторовича с шестидесятилетием, желаем ему доброго здоровья и новых творческих успехов. 